one species as feed for another. The Southwood report to the British agriculture ministry last year valuably unravelled the likely origins of the disease among cattle, suggested measures (adopted by the government, which had no choice) to contain the spread of the disease among cattle, and left open the question of whether there are circumstances in which people might be similarly afflicted, possibly by consuming meat (or offal) from infected cattle. It is a chilling prospect, one certain to condition general approval of the decision of the British government and research councils to commission a package of studies bearing on the prevalence and causation of this and similar diseases (see page 196).

The question is the more chilling because the evidently infectious organisms responsible for scrapie and BSE are still obscure. It is bad enough for people's capacity to sleep the whole night through that there should be viruses, such as that responsible for AIDS, to which there is as yet no certain defence. What is to be made of an infectious agent yet to be characterized? It is no disrespect to Stanley Prusiner, of the University of California at San Francisco, and to his advocacy of the notion that the infectious agent is a piece of protein molecule called a 'prion' to suggest that speculation about the causation of disease can be the only guide while so little can be learned in the laboratory about prions and their function.

That is why it is important that the British government's decision to back research in the field should not be misinterpreted, or the significance of its decision exaggerated. The circumstantial evidence assembled by the Southwood committee for believing that cattle acquire their illness by being fed sheep offal is strong, for which reason the banning of that practice (if thoroughly enforced) should quickly bring the disease among cattle to a halt. But that is also the best way of fending off the chance that people might eventually be infected. The interdiction on the sale of infected cattle to abattoirs is likely to be less effective, not simply because there may be some farmers eager to sell afflicted cattle for more than the government pays in compensation, but because there is no way in which infected cattle not showing symptoms of disease can be spotted on the way to slaughter. Yet if Southwood is correct, and if the regulations now in force are effective, the epidemiologists (of cattle) soon to begin work should have the pleasure of recording a disease in decline.

It is also important that what may prove to be a passing scare about people's health should not be taken as yet another sign that there is something rotten at the heart of modern society - the original sin of the affluent. Even the practice of feeding processed sheep offal to cattle may legitimately be regarded as a means of economizing in natural resources that, in other circumstances, would be known by the green epithet of 'recycling'. That it has been discovered to be an unsafe practice (for cattle), at least when sheep are afflicted by scrapie, is fortunate rather than a cause for shame. The idea that people might ultimately be affected is a hypothesis only, but one that must not be put to the test.

\section{Religious strife}

Communal unrest in Azerbaijan can be ended only if the Soviet Union hastens the process of economic reform.

Mr Mikhail Gorbachev's latest trouble, in Azerbaijan, is serious and will not easily be resolved, either in Baku (the republic's capital on the Caspian) or in Moscow. In the south, the difficulty has been evident for at least two years, during which Armenians and their Azeri neighbours have been on tenterhooks about the Armenian enclave of Nagorno Karabakh, a mountainous region within Azerbaijan. Disappointingly, communal conflict was hardly interrupted by the damaging earthquake in Armenia just over a year ago, but it is far from clear why the Azeri population should apparently have taken up arms against Armenian residents of Azerbaijan so soon after prevailing on Moscow to end direct rule in the disputed territory. On the face of things, that looks like a serious miscalculation. Meanwhile, the big surprise and the chief cause for everybody's alarm -- is that so many of those living in the region appear to be able to put their hands on a rifle or some other kind of firearm.

Moscow has no choice but to restore order, whatever kind of settlement may be on the cards. Governments owe even minority populations no less. It is also unthinkable that the Soviet government should withdraw the troops now on the way to Azerbaijan without also disarming the local population, no simple matter. But there is no obvious way in which the status quo can be restored in Azerbaijan, for the underlying conflict is religious. The far south has become the Soviet Union's equivalent of the British government's difficulty in Ulster. That should be a proof, if one were needed, of how obdurate these problems are. And although Gorbachev promised, in Lithuania last week, that there would soon be a draft statute to regulate the ways in which individual republics would be allowed to distance themselves from the Soviet Union proper, while remaining part of a federation, he had little to say about the most difficult part of that exercise - the protection of minorities' rights.

In Moscow, the argument will be for still higher stakes. Gorbachev will not be able to deny that the trouble in the south would never have broken out had it not been for glasnost and what has flowed from that - the legitimization of dissent and of public protest in particular. There will be plenty of people ready with that complaint, to which the only true response is that conditions elsewhere in the Soviet Union would now be much worse if people were still prevented from saying what they think, as in the old days. The pity, for Gorbachev's cause, is that perestroika has so far lagged behind glasnost. As in Ulster, it is probably too late now to restore communal peace in Azerbaijan by the promise of prosperity to come. Only the reality of prosperity would do that, which is yet another reason for hastening the process of reform. Even Gorbachev's opponents must now acknowledge that. 